\title{
Corporate Taxation and BEPS: A Fair Slice for Developing Countries?
}

Irene Burgers \& Irma Mosquera*

\begin{abstract}
The aim of this article is to examine the differences in perception of 'fairness' between developing and developed countries, which influence developing countries' willingness to embrace the Base Erosion and Profit Shifting (BEPS) proposals and to recommend as to how to overcome these differences. The article provides an introduction to the background of the OECD's BEPS initiatives (Action Plan, Low Income Countries Report, Multilateral Framework, Inclusive Framework) and the concerns of developing countries about their ability to implement BEPS (Section 1); a non-exhaustive overview of the shortcomings of the BEPS Project and its Action Plan in respect of developing countries (Section 2); arguments on why developing countries might perceive fairness in relation to corporate income taxes differently from developed countries (Section 3); and recommendations for international organisations, governments and academic researchers on where fairness in respect of developing countries should be more properly addressed (Section 4).
\end{abstract}

Keywords: Fairness, international tax, legitimacy, BEPS, developing countries

\section{Introduction}

\subsection{OECD's BEPS Action Plan, Low Income Country Report, Multilateral Instrument and Inclusive Framework}

\subsubsection{BEPS Action Plan}

In 2013 the G20 meeting in St. Petersburg ${ }^{1}$ endorsed the Base Erosion and Profit Shifting (BEPS) Action Plan. In its Action Plan, the OECD calls for 'fundamental changes to the current mechanisms and the adoption of new consensus-based approaches, including antiabuse provisions, designed to prevent and counter base erosion and profit shifting'. According to the OECD, aggressive tax planning 'undermines the fairness and

* Irene Burgers is Professor of International and European Tax Law, Faculty of Law, and Professor of Economics of Taxation, Faculty of Business and Economics, University of Groningen. Irma Mosquera, Ph.D. is Senior Research Associate at the International Bureau of Fiscal Documentation IBFD and Tax Adviser Hamelink \& Van den Tooren.

1. G20 Leaders Declaration meeting in St. Petersburg including the Tax Annex to G20 leaders declaration; see <https://www.oecd.org/g20/ summits/saint-petersburg/Tax-Annex-St-Petersburg-G20-LeadersDeclaration.pdf> (last visited 22 March 2017). integrity of tax systems because businesses that operate across borders can use BEPS to gain a competitive advantage over enterprises that operate at a domestic level. Moreover, when taxpayers see multinational corporations legally avoiding income tax, it undermines voluntary compliance by all taxpayers.' ${ }^{2}$ Aggressive tax planning has 'led to a tense situation in which citizens have become more sensitive to tax fairness issues'. ${ }^{3}$

The OECD does not provide for a definition of aggressive tax planning, but it does provide a definition of Base Erosion Profit Shifting: 'Base erosion and profit shifting (BEPS) refers to tax planning strategies that exploit gaps in the architecture of the international tax system to artificially shift profits to places where there is little or no economic activity or taxation.' This definition is more or less similar to what European Commission perceives as aggressive tax planning. According to the European Commission, aggressive tax planning 'exploits the differences in tax systems by taking advantage of the technicalities of a tax system or of mismatches between two or more tax systems for the purpose of reducing tax liability'. ${ }^{4}$ Therefore, presumably the OECD refers to the type of tax planning that results in BEPS.

The OECD stated that all parties, governments and individual taxpayers are harmed including also business since 'fair competition is harmed by the distortions induced by BEPS'. 5 Therefore, the OECD developed fifteen Actions including among others, actions dealing with hybrid mismatches, limitation of interest deductions, actions recommending the introduction of $\mathrm{CFC}$ rules, rules to prevent the artificial avoidance of $\mathrm{PE}$ status, eliminating harmful tax regimes, dealing with tax treaty abuse and with transfer pricing, the disclosure of aggressive tax planning arrangements, and improvement

2. See 'About BEPS and the inclusive framework', <www.oecd.org/tax/ beps-about.htm> (last visited 22 March 2017). Fairness is one of the tax principles the OECD formulated in its Ottawa Tax Framework, as revised in 2005 by the OECD Technical Advisory Committee (TAC). As to the OECD, "this principle implies that the potential for tax evasion and avoidance should be minimised while keeping counteracting measures proportionate to the risks involved'. OECD, Addressing the Tax Challenges of the Digital Economy, Action 1 - 2015 Final Report, OECD/G20 Base Erosion and Profit Shifting Project (2015), at 17; see <http://dx.doi.org/10.1787/9789264241046-en> (last visited 22 March 2017).

3. OECD, Action Plan on Base Erosion and Profit Shifting (2013), at 8; see<http://dx.doi.org/10.1787/9789264202719-en> (last visited 22 March 2017).

4. The European Commission Recommendation of 6 December 2012 on Aggressive Tax Planning C (2012)8806 Final, at 2.

5. OECD, above n. 3, at 8 . 
of the mutual agreement procedure. The content of the BEPS Actions was decided and approved by the BEPS 44 group, which includes OECD, OECD accession countries and G20 countries. ${ }^{6}$ This article focuses on the developing countries that are for the purpose of this article defined as non-OECD, non-G20 countries and are therefore not represented in the BEPS 44 group. $^{7}$

\subsubsection{Will BEPS Reduce Aggressive Tax Planning?}

A question that, to our best knowledge, neither the OECD nor IMF, UN or World Bank addressed, but has been addressed in academic literature, is whether BEPS will contribute to more economic fairness by reducing the incentive of multinationals to use aggressive tax planning. Martin Thomsen and Christoph Watrin found no evidence that multinationals are more tax aggressive than domestic firms. Their findings do not support the need for a coordinated international tax policy to prevent base erosion nor suggest that multinational companies should be blamed. Thomsen and Watrin call for governments to carefully consider the steps they take to address the OECD's BEPS project as well as for future research clarifying the concept of tax avoidance for international tax policy debates. ${ }^{8}$

6. The BRICS countries are regarded as emerging economies and even though these countries are non-OECD countries, they have a role in decision making by being members of the $G 20$ and by participating on equal footing in the BEPS 44 group. BRICS stands for Brazil, Russia, India, China and South Africa.

7. This article uses the distinction between developed and developing countries to distinguish between countries members of the OECD or G20 (developed countries) and other countries (developing countries). This classification is useful for the purposes of this article, which is to differentiate between OECD and G20 vs. non-OECD, non-G20 countries. This has also been the approach of the OECD when addressing Low Income Countries in its 2014 report. However, other classifications of countries may exist in scholarship taking into account the economic GDP (e.g. emerging economies), the dependence on aid, and the lack of a modernised tax administration, among others. See, for an economic approach between developed and emerging economies, the Emerging and Growth Leading Emerging Economies EAGLEs 2014 Economic Outlook made by the BBVA (a bank) Research Unit; see <https://www. bbvaresearch.com/KETD/fbin/mult/2014_EAGLEs_Economic_OutllokAnnual_tcm348437158.pdf?ts=3132014> (last visited 22 March 2017). Taking a legal perspective, Mosquera, when analysing in a 2015 publication the aggressive tax planning in South America and Sub-Saharan Africa, has argued that no one size fits all. The author also argued that the economic development of the countries in South America and SubSaharan Africa is different among countries and among regions. In order to find these differences, Mosquera provided a comparative analysis of the rules to deal with aggressive tax planning in South America and Sub-Saharan African regions taking into account the country's economic development, tax administration capacity and resources, and the use (or not) of domestic laws and tax treaty rules to tackle aggressive tax planning. The author concluded that from these regions some countries may be sensitive to BEPS issues including aggressive tax planning while for other countries aggressive tax planning is not yet the main issue since these countries are at the early stages of developing their own tax systems. See I.J. Mosquera Valderrama, 'The BEPS Measures to Deal with Aggressive Tax Planning in South America and Sub-Saharan Africa: The Challenges Ahead', 43 Intertax 10, at 615-27 (2015).

8. M. Thomsen and C. Watrin, Do We Really Need the BEPS Project?; see $<$ https://business.illinois.edu/accountancy/wp-content/uploads/sites/ 12/2015/09/Tax-2015-Thomsen-Watrin.pdf> (last visited 22 March 2017).

\subsubsection{Lom Income Countries Report Part 1 and 2}

In its 2014 Report to G20 Development Working Group on the impact of BEPS in Low Income Countries ('2014 Report') Part 1 and Part 2, ${ }^{9}$ the OECD identified the following differences on the basis of a questionnaire sent to developing countries, direct consultations with developing countries and the experiences of four international organisations (IOs):

a. The nature of cross-border tax planning may differ between developing and developed countries;

b. Developing countries may lack the necessary legislative measures needed to address BEPS;

c. Accessing relevant information is often difficult;

d. Building and maintaining capacity to implement highly complex international rules leave room for discretion in their application;

e. Need for political impetus and support for effective measures to counter BEPS highlighted in regional consultations;

f. The acute pressures on developing countries to attract investment can trigger a competitive 'race to the bottom'.

OECD has also mapped the following Actions that developing countries consider as the most important for developing countries: ${ }^{10}$

- Action 4 - Limit base erosion via interest deductions and other financial payments;

- Action 6 - Prevent treaty abuse;

- Action 7 - Prevent the artificial avoidance of PE status;

- Action 10 - Assure that transfer pricing outcomes are in line with value creation - other high-risk transactions;

9. In the first part of the Report, the OECD evaluates the impact of the Action Plan in Low Income Countries and it adds other issues that should be considered for these countries that are not included in such action plan (e.g. use of tax incentives by developing countries). In the second part of the Report, the OECD presents the potential actions to assist developing countries to meet the challenges of the most relevant actions of BEPS. OECD, Part 1 of a Report to G20 Development Working Group on the Impact of BEPS in Low Income Countries (2014); see $<$ https://www.oecd.org/g20/topics/taxation/part-1-of-report-to-g20dwg-on-the-impact-of-beps-in-low-income-countries.pdf> (last visited 22 March 2017). OECD, Part 2 of a Report to G20 Development Working Group on the Impact of BEPS in Low Income Countries (2014); see $<$ https://www.oecd.org/g20/topics/taxation/part-2-of-report-to-g20dwg-on-the-impact-of-beps-in-low-income-countries.pdf> (last visited 22 March 2017).

10. According to the reporters of medium importance are:

- Action 1 - Address the tax challenges of the digital economy;

- Action 5 - Counter harmful tax practices more effectively;

- Action 8 - Assure that transfer pricing outcomes are in line with value creation - intangibles;

- Action 9 - Assure that transfer pricing outcomes are in line with value creation - risks and capital;

- Action 12 - require taxpayers to disclose their aggressive tax planning arrangements;

- Action 14 - Make dispute resolution mechanisms more effective: and of low importance for developing countries are:

- Action 2 - Neutralise the effects of hybrid mismatch arrangements;

- Action 3 - Strengthen controlled foreign company rules;

- Action 15 - Develop a multilateral instrument. 
- Action 11 - Establish methodologies to collect and analyse data on BEPS and the actions to address it;

- Action 13 - Re-examine transfer pricing documentation.

The OECD recognises in this Report that developing countries have other needs than developed countries in respect of both tax design and tax administration, and that the BEPS issues may manifest differently for developing countries given the specialties of their legal and administrative governing framework. The OECD furthermore states that a further issue for 'developing countries, which was raised during the regional consultations, is the balance between source and residence taxation embodied in bilateral tax treaties modelled on the OECD and UN Model Tax Conventions. This is an issue of allocating taxing rights between two treaty partners. It is not a tax planning/avoidance issue and does not give rise to BEPS.'11 Despite being outside the scope of BEPS, the OECD stated in the 2014 Report that 'this is an issue of significance for many developing countries, and that the OECD/G20 BEPS Project provides an opportunity to lay the ground for this legitimate debate'. ${ }^{12}$ To the authors' knowledge, no further reference has been made to the fairness of the present allocation of taxing rights between treaty partners' allocation of taxing rights in the BEPS Actions nor in the discussion draft of the BEPS Multilateral Instrument. ${ }^{13}$

\subsubsection{Multilateral Instrument}

In October 2015, the OECD presented to the G20 Meeting of Finance Ministers in Lima (Peru), the final package of the fifteen Actions for a comprehensive, coherent and co-ordinated reform of the international tax rules. Among these Actions, Action 15 provides for a Multilateral Instrument.

In the discussion of this Multilateral Instrument not only countries of the BEPS 44 group are participating but developing countries are also participating. Developing countries have been invited to participate what the OECD refers to as 'on equal footing' in this discussion. The participation on equal footing by developing countries was introduced by the OECD to address the concerns of legitimacy and participation of developing countries that did not belong to the BEPS 44 group. For this purpose, the OECD set up an Ad Hoc Group to develop the BEPS Multilateral Instrument and to

11. OECD (2014), above n. 9, at 9; see <https://www.oecd.org/g20/ topics/taxation/part-1-of-report-to-g20-dwg-on-the-impact-of-beps-in -low-income-countries.pdf> (last visited 22 March 2017).

12. Ibid

13. Neither the report on Action 15 of the BEPS Action Plan nor the Public Discussion draft mention the allocation of taxing rights. See OECD, Developing a Multilateral Instrument to Modify Bilateral Tax Treaties, Action 15 - 2015 Final Report (2015); see <http://dx.doi.org/10.1787/ 9789264241688-en> (last visited 22 March 2017) and OECD, Public Discussion Draft BEPS Action 15: Development of a Multilateral Instrument to Implement the Tax Treaty Related BEPS Measures (2016); see $<$ www.oecd.org/tax/treaties/BEPS-Discussion-draft-MultilateralInstrument.pdf> (last visited 22 March 2017). address mainly Actions 2, 6, 7 and $14 .{ }^{14}$ This Ad Hoc Group includes more than hundred countries (OECD and G20 countries, developing countries), as well as a number of non-State jurisdictions and international organizations participating as Observers. ${ }^{15}$ This Multilateral Instrument has been adopted in the meeting on 24-25 November 2016. ${ }^{16}$

\subsubsection{Inclusive Framemork}

In the Meeting in Kyoto, Japan (29 June 2016-1 July 2016) the OECD presented an inclusive framework for the implementation of BEPS. This Inclusive Framework allows countries and jurisdictions outside the BEPS 44 group to participate as BEPS Associates on the implementation of BEPS. The BEPS Project and its Inclusive Framework contains four minimum standards Actions $5,{ }^{17} 6,{ }^{18} 13^{19}$ and $14^{20}$ that should be implemented into the tax system of the countries participating in this framework. The other Actions (1-4 and 7-12) comprise recommendations and best practices for countries to implement. At the time of writing this article, more than ninety countries are participating in the BEPS Inclusive Framework. ${ }^{21}$

\subsubsection{Problems of Legitimacy}

The current developments on the BEPS project show that not only the countries that are members of the BEPS 44 group, but also developing countries are participating in the discussion of the BEPS Multilateral Instrument and as BEPS Associates in the Inclusive Framework to implement BEPS Actions.

Against this background, the authors argue that the participation on equal footing of developing countries in the BEPS Multilateral Instrument and the Inclusive Framework are not sufficient to legitimise the role of the OECD and the BEPS 44 group in setting international tax standards for developing countries. The reason is that there has not been a true decision-making process

14. These actions deal with hybrid mismatches, treaty abuse, permanent establishment and mutual agreement procedure. According to the OECD, the negotiation in the ad hoc Group was focused on how the Convention would need to modify the provisions of bilateral or regional tax agreements in order to implement those measures. See OECD, A Mandate for the Development of a Multilateral Instrument on Tax Treaty Measures to Tackle BEPS, Action 15 - 2015 (2015); see <www. oecd.org/ctp/beps-action-15-mandate-for-development-of-multilateral -instrument.pdf> (last visited 22 March 2017).

See explanatory statement to the multilateral instrument $<$ https://www. oecd.org/tax/treaties/explanatory-statement-multilateral-convention-to -implement-tax-treaty-related-measures-to-prevent-BEPS.pdf> (last visited 22 March 2017).

15. See <www.oecd.org/tax/treaties/multilateral-instrument-for-beps-taxtreaty-measures-the-ad-hoc-group.htm> (last visited 22 March 2017).

16. See <www.oecd.org/tax/countries-adopt-multilateral-convention-toclose-tax-treaty-loopholes-and-improve-functioning-of-international-tax -system.htm> (last visited 22 March 2017).

17. Countering Harmful Tax Practices more effectively, taking into account transparency and substance.

18. Preventing the granting of treaty benefits in inappropriate circumstances.

19. Transfer Pricing Documentation and Country by Country Reporting

20. Making Dispute Resolutions more Effective.

21. See <www.oecd.org/tax/beps/inclusive-framework-on-beps-composi tion.pdf> (last visited 22 March 2017). 
since the content of BEPS Actions has been decided by the BEPS 44 group with developing countries having only a consultative role. The analysis of legitimacy and participation of developing countries has been made by Mosquera elsewhere. ${ }^{22}$

\subsubsection{Why Are Developing Countries Participating in the BEPS-Project?}

Despite the problems of legitimacy and the different needs of developing countries, developing countries such as Nigeria, Burkina Faso, Senegal, Bangladesh, Eritrea, Sri Lanka and Pakistan amongst others are participating in the inclusive framework to implement BEPS. ${ }^{23}$ It is not clear why these developing countries are participating in BEPS. To the authors' best knowledge, no research is available on this issue. Some indication of the reason that these countries are participating in BEPS could be found in their need to receive technical assistance and to gain more specialised knowledge on transfer pricing. ${ }^{24}$ These have been some of the concerns addressed by developing countries in the questionnaire on BEPS issues developed by the UN Subcommittee on BEPS for developing countries. The response to this questionnaire was limited since only four developing countries replied (Tonga, Lesotho, Ghana and Zambia). ${ }^{25}$ Surprisingly enough, these four countries are not participating in the inclusive framework for reasons that have not yet been investigated. Research on the reasons why countries have adopted BEPS is outside the scope of this article; this article focuses on the different perspective of fairness between developing and developed countries. Further research is recommended on the motivation of developing countries to participate in BEPS and the specific problems in the implementation of BEPS in developing countries.

22. I.J. Mosquera Valderrama, 'Legitimacy and the Making of International Tax Law: The Challenges of Multilateralism', 7 World Tax Journal 3, 343, at 382 (2015).

23. See <www.oecd.org/tax/beps/inclusive-framework-on-beps-composi tion.pdf> (last visited 22 March 2017).

24. M. Moore, H.O. Fjeldstad, J. Isaksen, O. Lundstøl, R. McCluskey \& W. Prichard, 'Building Tax Capacity in Developing Countries', 96 IDS Policy Briefing, Institute of Development Studies (2015).

25. The UN has addressed the BEPS issues from the perspective of developing countries. For this purpose, a questionnaire on BEPS issues was made available also including background papers drafted by legal scholars regarding specific topics. The responses to the questionnaire by developing countries were limited since only Lesotho, Ghana, Tonga and Zambia provided short answers to the questionnaire. Two of the main issues that these countries addressed were the implementation of domestic rules and the administrative capacity. In respect of implementation of domestic rules the countries mentioned the introduction of guidelines to apply the arm's length principle in transfer pricing (Tonga); implementation of tax avoidance rules (Zambia); lack of database to conduct the comparability analysis in respect of transfer pricing (Ghana); to prevent the tailoring of activities by multinationals so that such activities will not be deemed to constitute a permanent establishment in the developing country (Zambia). In respect of administrative capacity, Lesotho made reference to the limited skills to audit some of the highly specialised sectors. See Valderrama (2015), above n. 7, 615, at 619.

\subsubsection{Concerns of Developing Countries on Lack of Technical Resources}

As mentioned in the OECD's Low Income Report, the lack of technical resources, personnel capacity, technical knowledge and economic means of developing countries constitutes a challenge for these countries to implement measures concerning international assistance. This most likely is also the case for the BEPS Multilateral Instrument and the BEPS four minimum standards and to achieve outcomes favourable to them.

In September 2016, in a regional meeting of the inclusive framework of BEPS for non-OECD countries in Latin America and the Caribbean, some participant countries expressed their 'concerns on the consequences derived from not being able to partially or fully implement the BEPS measures contemplated in the inclusive framework, considering their own priorities and specific countries' features' ${ }^{26}$ In addition, in November 2016, in a regional meeting of the inclusive framework of BEPS in African French speaking (non-OECD) countries, the participating countries expressed their need for capacity building and training. ${ }^{27}$ These countries also highlighted the importance of finding out the costs and benefits that the implementation of BEPS Actions will cause in their domestic revenue and the need of these countries to maintain some of their preferential tax regimes in order to attract investment. ${ }^{28}$ Furthermore, these countries asked for more flexibility in the time schedule and on the methodology to be used to implement the BEPS minimum standards. ${ }^{29}$ If the BEPS Inclusive Framework does not take into account these shortcomings, the consequences will be a partial implementation of BEPS or an implementation of BEPS in theory but in practice a lack of commitment to the BEPS.

\subsubsection{Different Perspectives on Fairness}

Different perspectives on fairness between developed and developing countries will influence the implementation of the BEPS Actions including the BEPS Multilateral instrument. In light of the BEPS Project as well as the need of developing countries to raise revenue to ach-

26. Regional meeting of the Inclusive Framework on BEPS for Latin America \& the Caribbean. Montevideo, Uruguay, 21-23 September 2016. Cochair summary, at 3; see <www.oecd.org/tax/beps/beps-regionalmeeting-co-chairs-summary-lac-september-2016-montevideo.pdf> (last visited 22 March 2017)

27. OECD and CREDAF hold regional meeting of the Inclusive Framework on BEPS for francophone countries; see <www.oecd.org/ctp/oecd-holds -regional-meeting-of-the-inclusive-framework-on-beps-for-francophone -countries.htm> (last visited 22 March 2017).

28. Chair summary 4; see <https://www.oecd.org/fr/fiscalite/beps/resumeco-presidents-reunion-regionale-du-cadre-inclusif-beps-tunis-2016.pdf> (last visited 22 March 2017).

29. Ibid. Chair summary conclusion. 
ieve the SDGs,${ }^{30}$ this article aims to provide a discussion of the concept of fairness in respect of developing and developed countries implementing the BEPS Actions. This article aims to answer the following questions: Is the perception of fairness between developing countries and developed countries the same or different? And if different, what, if anything, can be done to achieve fairness for both developed and developing countries?

This article does not aim to provide a definition of fairness. ${ }^{31}$ The focus of this article is on the approach to fairness from an international perspective, i.e. fairness between the states. Whether and how the BEPS Project and Action Plan will contribute to fairness from the perspective of justice in the BEPS 44 group and in developing countries that are participating as BEPS Associates in the BEPS Inclusive Framework is not clear. To our best knowledge, no research report on this issue is available.

\subsubsection{Structure and Limitations}

We first address the shortcomings of the BEPS project in respect of developing countries addressed by tax scholars and by international organisations (Section 2). Thereafter, we offer some arguments on why developing countries might perceive fairness in relation to corporate income taxes differently from developed countries (Section 3). Subsequently, we provide some examples of policy issues where the issue of fairness should be addressed more profoundly and in a broader context on the international BEPS-agenda than thus far, where the OECD's and EU's focus was on achieving a level playing field and voluntary compliance (Section 4).

30. In their Global Framework for Financing Development Post-2015 Program the Heads of State and Government and High Representatives gathered in Addis Abba from 13 to 16 July 2015 recognised 'that significant additional domestic public resources, supplemented by international assistance as appropriate, will be critical to realizing sustainable development and achieve the SDGs'. Furthermore, they committed to 'enhance revenue administration through modernised, progressive tax systems, improved tax policy and more efficient tax collection'; and to 'work on improving the fairness, transparency, efficiency and effectiveness of their tax systems, including by broadening the tax base and continuing efforts to integrate the informal sector into the formal economy in line with country circumstances'; see <www.un.org/esa/ffd/ ffd3/wp-content/uploads/sites/2/2015/07/Addis-Ababa-Action-

Agenda-Draft-Outcome-Document-7-July-2015.pdf> (last visited 22 March 2017).

At the United Nations Sustainable Development Summit on 25 September 2015, world leaders adopted the 2030 Agenda for Sustainable Development, which includes a set of 17 Sustainable Development Goals (SDGs) to end poverty, fight inequality and injustice, and tackle climate change by 2030; see <www.undp.org/content/undp/en/home/ sdgoverview/post-2015-development-agenda.html> (last visited 22 March 2017).

31. Fairness from a conceptual and an institutional perspective will be the subject of another article from these authors. See 'Fairness: A Dire International Tax Standard with No Meaning?' (forthcoming).

\section{Shortcomings of BEPS in Respect of Developed and Developing Countries}

\subsection{Introduction}

Are the BEPS Actions truly the best option for creating a level playing field for and voluntary compliance by their companies? Some developed countries have expressed their concerns and have decided to act unilaterally by introducing their own rules. An example of the former is the United States where the Congress has expressed concern in the negotiation of a BEPS Multilateral Instrument, stating that 'regardless of what the Treasury Department agrees to as part of the BEPS project, Congress will craft the tax rules that it believes work best for U.S. companies and the U.S. economy'. ${ }^{32}$ The latter has been the case in Australia and the United Kingdom, two countries that have decided to introduce their own (domestic) rules to deal with shifting of profits by multinationals (i.e. diverted profit tax). The introduction of these unilateral measures shows the lack of commitment to the consensual approach of BEPS.

Australia's and the United Kingdom's unilateral initiatives have received criticism from the Director of the OECD's Centre for Tax Policy, stating that 'what is clear is that without coherent, global approaches, problems like those that gave rise to BEPS are likely to arise again - it is the mismatches and gaps between national tax systems, along with the international rules, that have facilitated these types of tax planning arrangements and allow the location of taxation to be separated from the underlying economic activity. To effectively maintain their tax sovereignty in a globalised world, governments can no longer just consider their domestic system if they want their tax policies to be effective. ${ }^{33}$ To the authors' knowledge, no other country has introduced similar taxes. $^{34}$

In this context, the question that should be asked is if these developed countries (members of the OECD and of the G20) have concerns on the likeliness that the BEPS proposals will be accepted and/or whether these

32. Letter of the Senate Finance Committee (Chairman Orrin G. Hatch) and House Ways and Means Committee (Chairman Paul D. Ryan) to the Secretary of the Treasury Jacob Lew of 9 June 2015; see <https://www. finance.senate.gov/chairmans-news/hatch-ryan-call-on-treasury-toengage-congress-on-oecd-international-tax-project> (last visited 22 March 2017)

33. Interview to OECD Pascal Saint-Amans March 2016; see <https:// taxlinked.net/blog/march-2016/beps-oecd-pascal-saint-amans-answers -questions>.

34. However, another tax that could also have issues of fairness is the recently (2016) proposed Equalization Levy to impose tax on specific digital transactions. This levy aims to allocate a 'fair share' on the tax of the income obtained in digital transactions. It is not yet clear whether this Equalization Levy will be approved by the Legislative and if it will survive the constitutional challenge in India. It is also not clear how the tax treaties will provide relief to this levy since this levy does not form part of the Indian Income Tax Act of 1961. See, for an analysis of this levy, S. Wagh, 'The Taxation of Digital Transactions in India: The New Equalization Levy', 70 Bulletin for International Taxation 9 (2016). 
proposals will be effective. As rightly stated by Ostwald, the question is 'who will adopt the BEPS after all?'35

In respect of developing countries that were outside the BEPS 44 Group and therefore did not participate in the decision-making process of the BEPS Action, this question is even more valid. Will developing countries adopt BEPS? And if so, how will the shortcomings of BEPS agenda and Actions in respect of developing countries be solved?

The development of a multilateral instrument and the introduction of an inclusive framework for the implementation of BEPS calls for the OECD and G20 to address the shortcomings of BEPS in respect of developing countries. These shortcomings are addressed in the following paragraphs. In Section 4 we provide some thoughts for further research on the fairness of BEPS vis-à-vis developing countries.

\subsection{Different Needs Identified by the Four IOs and Scholars}

\subsubsection{Different Needs of Developing Countries Identified by the Four IOs}

As has been mentioned, the OECD recognises in its Report to G20 Developing Working Group on the Impact of BEPS in Low Income Countries that developing countries have other needs than developed countries in respect of both tax design and tax administration, and that the BEPS issues may manifest differently for developing countries given the specialties of their

legal and administrative governing framework. Specific concerns that have been identified in the OECD's questionnaire and consultations and the IOs' experiences are: Tax loss on indirect transfer of assets; Lack of data for transfer pricing comparability analyses; Wasteful tax incentives that erode the tax base; and capacity development issues involving international assistance providers. Amongst others, IMF, UN and World Bank addressed these issues. $^{36}$

In 2014, the IMF published a Policy Paper on the Spillovers in International Corporate Taxation. ${ }^{37}$ In that paper, the IMF addressed the issue of tax incentives as one of the reasons for corporate tax spillover being the impact that one country's international tax practice has on other countries. The IMF stated that for developing countries, the key issues are preventing tax treaty shopping, indirect transfer of interest in assets, interest deductibility and the introduction of clear and simplified transfer pricing rules. ${ }^{38}$

In July 2015, following the invitation of the G20's Development Working Group the IMF, the OECD, the $\mathrm{UN}$ and the WB published a report with options for low-income countries' effective and efficient use of tax

35. T.P. Ostwal, 'Who Will Adopt the OECD's Plan against BEPS, after All?', Kluwer International Tax Blog (2015); see <http://tpostwal.in/ downloads/OECDs.pdf> (last visited 22 March 2017).

36. As acknowledged in OECD (2014), above n. 9, at 20.

37. IMF Policy Paper Spillovers in International Corporate Taxation, International Monetary Fund, Washington, DC, 9 May 2014.

38. Ibid., at 24 incentives for investment. ${ }^{39}$ This report provided recommendation on how support for developing tax capacity in developing countries can be improved. This report also identified other problems of developing countries, which include non-BEPS issues, that may result in tax base erosion or may reduce compliance. These problems are besides the use of tax incentives, the lack of technical and administrative capacity, and corruption. Some problems can be solved by means of technical assistance but others will need the political will for instance to tackle corruption, and to reduce or control the excessive use or length of tax incentives by developing countries.

This shows that international organisations are aware of the fact that the needs of developing countries are to some extent different from those of developing countries, as reflected in the OECD's Addressing the impact of BEPS in Low Income Countries Report (2014) and also argued by IMF (2014) and the July 2015 Report. Developing countries feel the scope of the BEPS discussion should be broadened to the use of tax incentives, the allocation of tax treaty rights in accordance with residence and source, the tax treaty costs/benefits analysis to be made for the negotiation of tax treaties, the finding of comparables for the application of transfer pricing rules and the limited administrative capacity of tax administration.

\subsubsection{Needs of Developing Countries Identified by Scholars}

Scholars also pointed out the differences in needs between developed and developing countries.

Wagenaar has rightly argued that some of the BEPS problems may not be relevant for developing countries and that, therefore, 'the proposed solutions could also have unexpected results in tax systems'. ${ }^{40}$ Wagenaar referred to specific issues in developing countries such as tax holidays, tax exemptions, reliance on sourcebased taxation, use of deemed profit regimes and the legal restrictions on activities by foreign investors that may restrict 'foreign companies to operate and structure transactions in certain ways'. ${ }^{41}$

This concern has also been shared by Oguttu in a twopart article regarding the analysis of BEPS Actions from

39. 'Options for Low Income Countries' Effective and Efficient Use of Tax Incentives for Investment'. A report to the G-20 Development Working Group by the IMF, OECD, UN and World Bank (September 2015), at 23; see <https://www.imf.org/external/np/g20/pdf/101515a.pdf> (last visited 22 March 2017).

40. L. Wagenaar, 'The Effect of the OECD Base Erosion and Profit Shifting Action Plan on Developing Countries', 69 Bulletin for International Taxation 2, 84, at 86 (2015)

41. For instance, Wagenaar explains that the 'setting up activities often requires business licences that restrictively list the activities that can be performed by the foreign investor. In addition, there may be obligations to register or get approval for any cross-border contracts that have been entered into by local subsidiaries. Extracting cash from operation companies may require special approvals under foreign exchange control or more general rules controlling foreign investment'. Ibid., at 87. 
an African perspective. ${ }^{42}$ For Oguttu, 'protecting the tax base of African countries involves adopting relevant provisions in their domestic laws and in the tax treaties that they conclude and, at the same time, being aware of the special needs and perspectives of the country in question, such as the state of development of the tax system and its administrative capacity'. ${ }^{43}$ According to Oguttu, the Actions that are important for African countries are - in line with the OECD's findings for its Low Income Report - Action 4, 6, 7, 10 and 13, and, remarkably different from the OECD's findings, not 11 but 12.44

In another article Oguttu addressed the problems in the implementation of the mutual agreement procedure, MAP (Action 14) and the role of the competent authorities (CA) in African countries. Oguttu argued that the OECD 'has issued a number of documents providing guidance regarding the effectiveness of MAPs'. However, the OECD's recommendations often favour the OECD member countries, which may not take into account the interests and administrative constraints of developing countries'. Therefore, Oguttu recommends that in line with international guidance on effective MAPs that has been provided by the minimum standards set out in the Final Report on Action 14 and the UN Guide on MAPs for developing countries, African countries should publish clear guidelines and procedures to access MAPs that clearly specify the circumstances in which MAPs will be applied, the time limits in which taxpayers can approach the CAs, who is the CA, what documentation is required to be submitted with the application for a MAP, the interaction of MAPs with domestic legislation and estimated timelines. $^{45}$

Lennard ${ }^{46}$ refers to the tension between source- and residence-based taxation on one hand, and the importance

42. A.W. Oguttu, 'OECD's Action Plan on Tax Base Erosion and Profit Shifting: Part 1 - What Should Be Africa's Response?', 69 Bulletin International Taxation 11 (2015) and see A.W. Oguttu, 'OECD's Action Plan on Tax Base Erosion and Profit Shifting: Part 2 - A Critique of Some Priority OECD Actions from an African Perspective - Addressing Excessive Interest Deductions, Treaty Abuse and the Avoidance of the Status of a Permanent Establishment', 70 Bulletin International Taxation 6 (2016).

43. Ibid.

44. Dealing respectively with limit base erosion via interest deductions and other financial payments, prevent treaty abuse, prevent artificial avoidance of permanent establishment, transfer pricing, disclosure of aggressive tax planning and transfer pricing documentation.

45. For developing countries, more specifically African countries, this author states that 'African countries need to ensure that MAPs function effectively, and that MAPS are transparent and accessible to taxpayers. African tax administrations should set aside funds to train their staff regarding MAPs. They should also be more active in supporting taxpayers who apply for MAPs and should not try to influence taxpayers to give up their right to MAPs, and taxpayers should not be prohibited, as part of settlement negotiations with tax administrations, from claiming the full amount of tax suffered in exchange for not proceeding with a MAP'. A.W. Oguttu, 'Resolving Treaty Disputes: The Challenges of Mutual Agreement Procedures with a Special Focus on Issues for Developing Countries in Africa', 70 Bulletin for International Taxation 12 (2016).

46. M. Lennard, 'Base Erosion and Profit Shifting and Developing Country Tax Administrations', 44 Intertax 10, at 745 (2016). of withholding taxes to many countries on the other, but also the issues it raises for taxpayers. As to Mosquera for developing countries, issues that should be addressed, which are not BEPS-related issues, are 'the transparency in respect of the extractive industry, the consequences of the repeal of tax incentives in respect of the bilateral investment treaties, the training required for tax treaty negotiations, and the usefulness (or not) of a multilateral instrument to modify tax treaties for countries that are at the early stages of concluding tax treaties'. ${ }^{47}$ Burgers et al. discussed the fact that BEPS issues may not be similar in developing countries as in developed countries and recommends developing countries to take notice of the way tax systems of developed countries have been exploited by taxpayers, among others, in structuring their finance, as well as of the anti-abuse measures that countries with more advanced tax systems have included in their tax systems; to identify to which extent their tax systems might be exploited in a similar way; and to decide on measures to counteract such abuse. ${ }^{48}$ The following paragraphs will provide our view on the problems regarding the implementation of the BEPS Actions in developing countries.

\subsection{BEPS Actions and Developing Countries}

\subsubsection{Introduction}

The above overview shows that international organisations and tax scholars have concerns regarding whether all BEPS Actions are relevant for developing countries, and on the feasibility of implementing BEPS Actions in developing countries. In this section, we provide our view on the relevance of BEPS Actions for developing countries. ${ }^{49}$ This description is by no means exhaustive. The focus is on the four BEPS Actions (5, 6, 13 and 14) regarded as minimum standards with some succinct reference to the other BEPS Actions. Further research is recommended on the feasibility of the implementation of the BEPS Actions considering the differences in tax systems and tax cultures of countries around the world

47. See Valderrama (2015), above n. 22, 381, at 382.

48. I.J.J. Burgers, J.N. Bouwman, N.J. Schutte \& A.J. van Herwaarden, 'Pay your taxes where you add the value: how to avoid tax avoidance and abuse? An overview of measures taken and proposed with a special focus on developing countries'. Paper presented at Pay your taxes where you add the value, The Hague, The Netherlands, 2015: 1-61; see $<$ www.rug.nl/research/portal/files/22877769/Pay_your_taxes_where_ you_add_the_valuetaxavoidance2900615def.pdf!null> (last visited 22 March 2017).

49. This analysis does not address Action 15, the BEPS Multilateral Instrument. For a discussion on the BEPS multilateral instrument, see R. García Antón, 'The 21st Century Multilateralism in International Taxation: The Emperor's New Clothes?', 8 World Tax Journal (2016); and see N. Bravo, 'The Multilateral Tax Instrument and Its Relationship with Tax Treaties', 8 World Tax Journal 3 (2016); see also I. Grinberg, 'The New International Tax Diplomacy', 104 Georgetown Law Journal 1137, at 1196 (2016) 
and the different problems felt by developing and developed countries. ${ }^{50}$

\subsubsection{Implementation Problems}

The lack of legitimacy in respect of the participation of developing countries in the agenda setting and the content of the BEPS Actions may also have an influence on the implementation of the BEPS Actions in developing countries. This has also been pointed out by Lennard ${ }^{51}$ stating that 'even for countries that have not been directly involved in the BEPS process there are aspects of it which may have generally positive domestic and international impacts. However, direct developing country involvement in the decision making process by countries that are neither OECD Members nor G20 countries has been very limited, and there is suspicion among many countries that their engagement on implementation is more zealously sought than their participation in setting the rules, and that those rules may not sufficiently reflect developing countries realities and priorities. $^{52}$

The BEPS Inclusive Framework has introduced four BEPS Actions as minimum standards that countries participating in this Framework will be required to implement. A peer review system has been introduced to review the legal and tax framework and the implementation of these minimum standards in these countries. ${ }^{53}$ These minimum standards are Actions 5, 6, 13 and 14 dealing respectively with eliminating harmful tax regimes, tax treaty abuse, country-by-country reporting requirements, and improvement of the mutual agreement procedure. In our view, developing countries will benefit from all these four Standards. However, for these Actions to be effective, we suggest these Actions should be tailored to developing countries and the problems in the implementation of these standards will need to be further analysed. Below we provide for a short overview of some of these implementation problems.

The differences in tax systems and tax cultures have been addressed in the past by tax scholars considering that the legal transplant of concepts may result in different outcomes due to the differences in tax systems and tax cultures in countries around the world. See C. Gabarino, 'Comparative Taxation and Legal Theory: The Tax Design Case of the Transplant of General Anti-Avoidance Rules', 11 Theoretical Inquiries in Law 2 (2010); see also I.J.J. Burgers, 'Some Thoughts on Further Refinement of the Concept of Place of Effective Management for Tax Treaty Purposes', 35 Intertax 6/7, 378, at 386 (2016); and see I.J. Mosquera, 'The Interaction of Tax Systems and Tax Cultures in an International Legal Order for Taxation', 5 Diritto e Pratica Tributaria Internazionale 2, CEDAM, Italy, 841, at 869 (2008); and see I.J. Mosquera, Leasing and Legal Culture - Towards Consistent behavior in Tax Treatment in Civil Law and Common Law Jurisdictions, at 352 (2007)

51. Michael Lennard is Chief International Tax Cooperation, United Nations.

52. M. Lennard, 'Base Erosion and Profit Shifting and Developing Country Tax Administrations', 44 Intertax 10, 744, at 745 (2016).

53. The OECD has announced that the first standard that will be reviewed and monitored will be Action 14; see <www.oecd.org/tax/beps/bepsaction-14-peer-review-and-monitoring.htm> (last visited 22 March 2016).
Action 5: Preferential Regimes Needed to Attract Investment

Action 5 deals with preferential tax regimes that can be qualified as harmful. However, countries need to have preferential tax regimes to attract investment and the question is how these harmful tax regimes will be evaluated, and how this evaluation can be detrimental to developing countries' own tax and investment policy. This concern has been expressed by French African speaking countries addressed in the regional BEPS Inclusive Framework meeting of November 2016 (see Section 1).

Action 5 and 13 Exchange of Business Information: Technical Capacity Problems

Action 5 and Action 13 introduce exchange of business information, the technical capacity of developing countries and the protection of confidentiality will also need to be evaluated. Action 5 introduces compulsory spontaneous exchange on rulings related to preferential tax regime. Action 13 deals with transfer pricing documentation that provides for exchange of documentation such as master file, local file and country-by-country reports among countries. The question that arises is how the confidentiality of the business and taxpayer information exchange in these Actions will be protected in developing and developed countries. ${ }^{54}$ Will developed countries introduce safeguards to limit the exchange with countries that do not have the same level of protection of taxpayer information as the developed country? The problems of automatic exchange of information should be addressed taking into account that due to the fast pace in which automatic exchange of information 'is going to take place, the result may be less control over the accuracy and use of the information by the receiving and supplying authorities'. 55

\section{Action 6 Tax Treaty Abuse: Technical Capacity Problems} Another Action that may be difficult for developing countries to implement is Action 6, which deals with tax treaty abuse. The problems may arise due to the limited technical capacity of developing countries to implement the limitation on benefits rule and/or the principal purpose test. Uncertainty of how tax administrations will interpret the new rules is another issue that is probably more prominent in developing countries than in developed countries.

Action 14 Peer Reviem of Mutual Agreement: Lack of (Meaningful) $M A P-R u l e s$

The final minimum standard to be implemented is Action 14 dealing with mutual agreement procedure. The terms of reference for the peer review has identified four key areas: preventing disputes, availability and access to MAP, resolution of MAP cases, and imple-

54. See also F. Debelva and I.J. Mosquera, 'Privacy and Confidentiality in Exchange of Information Procedures: Some Uncertainties, Many Issues, But Few Solutions', Intertax, forthcoming May 2017.

55. See Valderrama (2015), above n. 22, 371, at 377. 
mentation of MAP agreements. ${ }^{56}$ The schedule of peer review has been already published and the peer review of the first batch of countries will start on December 2016. ${ }^{57}$ Interesting in this schedule is that the peer review for most of the developing countries has been deferred until 2020. ${ }^{58}$ The reason for this deferral is stated in the terms of reference: 'the MAP Forum should defer the review of any such member that is a developing country and is not an OECD or G20 country if that member has not yet encountered meaningful levels of MAP requests and there is no feedback from other members of the FTA MAP Forum indicating that the jurisdiction's MAP regime requires improvement' ${ }^{59}$ This statement acknowledges the lack of MAP rules in developing countries. Surprisingly enough, the terms of reference do not refer to the UN guidelines on mutual agreement procedure, which can be used by developing countries to introduce MAP rules. ${ }^{60}$ The question is whether the terms of reference will take into account the technical and administrative constrains of developing countries to introduce MAP rules and to provide an effective solution to tax disputes by means of the MAP. This concern has been also highlighted by Oguttu when addressing the problems in the implementation of MAP rules in African countries (Section 2.2.2).

\section{Other BEPS Actions}

Other BEPS Actions, i.e. 1-4 and 7-12, are regarded as best practices and recommendations. Due to the space constraint in this article, below we only briefly address the implementation of these Actions in developing countries. In our view, Actions 7 (permanent establishment) and Actions 8-10 (transfer pricing) are more relevant for developing countries.

Action 1 and 4 (respectively digital economy and limitation on interest deductions) can be dealt with in domestic law by levying a tax on digital services or by means of specific targeted anti-avoidance rule in combination with a general anti-avoidance rule. However, we feel, for level playing field reasons, it would be best if all countries introduce more or less similar rules. The different views on equality and certainty discussed in Section 3.2

56. Terms of reference available at the OECD website; see $<w w w$.oecd.org/ tax/beps/beps-action-14-on-more-effective-dispute-resolution-peerreview-documents.pdf>

57. These countries are Belgium, Canada, The Netherlands, Switzerland, the United Kingdom and the United States.

58. The countries for which peer review has been deferred until 2020 are Benin, Costa Rica, Egypt, Gabon, Georgia, Jamaica, Kenya, Pakistan, Paraguay, Senegal, Seychelles, Uruguay; see <https://www.oecd.org/ tax/beps/beps-action-14-peer-review-assessment-schedule.pdf>.

59. OECD, BEPS Action 14 on More Effective Dispute Resolution Mechanisms - Peer Review Documents, OECD/G20 Base Erosion and Profit Shifting Project (2016), at 20; see <www.oecd.org/tax/beps/bepsaction-14-on-more-effective-dispute-resolution-peer-reviewdocuments.pdf>.

60. See, on the use of these guidelines for African countries, Oguttu; see $<$ www.un.org/esa/ffd/tax/gmap/Guide_MAP.pdf> (last visited 22 March 2017) will also be relevant for the implementation of these Actions. ${ }^{61}$

In respect of the implementation of Actions 2 and 3 (respectively hybrid mismatches and controlled foreign corporation rules) we feel the perception of developing countries expressed in the OECD's Low Income Countries Report Part 1 requires international governance actions in raising the awareness that the use of hybrid mismatches etc. is a global phenomenon.

Action 11, Measuring and Monitoring, BEPS Report, shows that the quantitative analyses of BEPS are severely constrained by limitations of the currently available data. Even the tax data directly controlled by governments is often not made public in a form useful for analysis. Limited government capacity for analysing the data already collected by tax authorities was demonstrated by the fact that only eight out of thirty-seven OECD Member States surveyed by the OECD could report the total amount of tax revenue collected from MNEs in their jurisdictions. Capacity problems as mentioned above are a main concern for developing countries, the reason why it is safe to state that developing countries will perceive even more problems with measuring BEPS than developed countries. ${ }^{62}$

\subsection{Inclusiveness and Multilateralism of BEPS}

\subsubsection{Is BEPS Really Inclusive Providing for Participation on 'Equal Footing'?}

Developing countries' 'participation on equal footing' in the discussion of the BEPS Multilateral Instrument and as BEPS Associate in the Inclusive Framework for implementation of BEPS raises the question as to whether the BEPS is inclusive or not.

The OECD seems to be aware of the importance of including developing countries in the discussion on the implementation of BEPS for legitimacy purposes. The OECD reports that, until the release of the BEPS Package in October 2015, approximately 60 developing countries have participated directly or indirectly in the process through regional consultations and thematic global Fora. Despite this participation, developing

61. E.g. JinYan Li in her paper 'Protecting the Tax Base in the Digital Economy' written at the request of the UN. She points out the digital economy poses two kinds of challenges to the tax base of developing countries: base erosion due to BEPS strategies; and base cyberization due to the dematerialisation and connectivity features of the digital economy. According to $\mathrm{Li}$, developing countries may need to develop their own measures, such as the taxation of services and royalties, as developing countries, being market countries, tend to be 'net losers' in tax revenue. Li calls for coordination between the UN and the OECD, as the special concerns of the developing countries may not be shared by the OECD. A. Trepelkov, H. Tonino \& D. Halka, United Nations Handbook on Protecting the Taks Base of Developing Countries (2015) 3; see <www.un. org/esa/ffd/wp-content/uploads/2015/07/handbook-tb.pdf> (last visited 22 March 2017). For the participation and representation of developing countries and the role of the UN see R.S. Avi-Yonah and H. Xu, 'Evaluating BEPS', University of Michigan Public Law Research Paper No. 493 (15 January 2016); see <http://ssrn.com/abstract=2716125> (last visited 22 March 2017) (discussed in Section 2.3 hereafter)

62. OECD, Measuring and Monitoring BEPS, Action 11 - 2015 Final Report (2015), at 37; see <http://dx.doi.org/10.1787/9789264241343-en> (last visited 22 March 2017). 
countries did not have a decision-making role in the setting of the BEPS agenda nor in the content of the BEPS Actions. The decision-making process was at the hand of the BEPS 44 group, and of course developing countries did not participate, nor were represented, in setting the agenda and in the decision-making process of the BEPS Action Plan that resulted in the 5 October BEPS final package. ${ }^{63}$ Following concerns of legitimacy, the OECD wanted to change this by introducing the participation on equal footing (thus also decision making) in the BEPS Multilateral Instrument (more than 100 countries including the BEPS 44 group) and in the BEPS Inclusive Framework (90 countries including the BEPS 44 group).

Although the OECD refers to the participation as being on 'equal footing', given developing countries are latecomers in the discussion, they have little capacity and probably also less knowledge on the topic than developed countries that this gives a too optimistic view of reality. Moreover, the participation in the discussion of the multilateral instrument and in the inclusive framework will not solve the problem of the lack of participation of developing countries in the setting of the agenda and the content of the BEPS Actions. The OECD's and other international organisations' acknowledgment of the different objectives demonstrates that even though the OECD and other international organizations are aware of the differences, these differences did not result in a tailor-made Action Plan for developing countries nor in specific caveats or options in the BEPS Actions to be applicable to developing countries.

This is more important if we are to consider the BEPS multilateral instrument, which modifies bilateral tax treaties around the world. ${ }^{64}$ Even though there is consensus for a multilateral agreement, as rightly stated by Eicke it is not clear whether the time will be right and 'how many compromises and mini package deals will be necessary to achieve an agreement that does not sacrifice the higher goals'. ${ }^{65}$ The BEPS multilateral instrument adopted in November 2016 confirms this statement since it provides several options for countries to adopt for instance in respect of the method to prevent double taxation in hybrid mismatches and on the content of the

63. See Valderrama (2015), above n. 22, 371, at 377

64. The explanatory statement explains the way that the bilateral and regional tax treaties will be modified with the BEPS Multilateral instrument stating that 'The Convention operates to modify tax treaties between two or more Parties to the Convention. It will not function in the same way as an amending protocol to a single existing treaty, which would directly amend the text of the Covered Tax Agreement; instead, it will be applied alongside existing tax treaties, modifying their application in order to implement the BEPS measures. As a result, while for internal purposes, some Parties may develop consolidated versions of their Covered Tax Agreements as modified by the Convention, doing so is not a prerequisite for the application of the Convention. As noted below, it is possible for Contracting Jurisdictions to agree subsequently to different modifications to their Covered Tax Agreement than those foreseen in the Convention'.

65. R. Eicke, 'A BEPS Multilateral Instrument - Practical Solution or Elusive Pipe Dream?', Tax Notes International (2014), at 528. provision dealing with treaty abuse. ${ }^{66}$ Countries will be required to revisit their tax treaties to find out which country will introduce which option, and then to start making the changes accordingly. This requires tax technical knowledge and treaty negotiation skills since the implementation of the option will need to be discussed in the domestic ratification procedure as well as with the other treaty partner. ${ }^{67}$

\subsubsection{Should the UN Take Leadership?}

The limited inclusiveness and participation of developing countries in the BEPS project have been argued by Reuven Avi-Yonah and Haiyan Xu referring to: (i) the OECD countries dominating the discussion and negotiations; (ii) (at the time) only 60 countries participating in the BEPS discussions in contrast to the UN representing 193 countries); (iii) there is no evidence that the proposals of developing countries that where consulted regarding the BEPS Action Plan were accepted; (iv) the limited influence of developing countries due to the limited experience and resources to enforce the BEPS Actions; and (v) the process of public debate and consulting being insufficient and without transparency since no publication has been made on the reasons for rejecting different proposals. Therefore, as to these authors the UN should take the leadership since the UN is 'more qualified, impartial, transparent, credible and influential than the OECD/G20 in rewriting and renovating the international tax rules including the BEPS counter-measures'. ${ }^{68}$

66. See text of the Multilateral Instrument Arts. 3-7 (Hybrid mismatches) and 7 (treaty abuse). The text of the BEPS Multilateral Instrument is available at the OECD Website; see <www.oecd.org/tax/treaties/ multilateral-convention-to-implement-tax-treaty-related-measures-toprevent-BEPS.pdf.

67. The Explanatory Statements states that para. 4 of Art. 29 Time Notifications 'provides that if notifications are not made at the time of signature, a provision al list of expected notifications shall be provided to the Depositary at that time. This provisional list is for transparency purposes only and is intended to give other Signatories a preliminary indication of the Signatory's intended position. This takes account of the nature of the Convention which will operate to modify existing bilateral or multilateral relationships and the options chosen by the other Contracting Jurisdictions will determine the way in which the existing bilateral or multilateral agreement is modified. Accordingly, provisional indications of intended positions are important to allow an understanding of the likely changes to an existing tax agreement and to facilitate domestic ratification procedures as well as to prepare for the implementation of the modifications made by the Convention. The provisional list of expected notifications under Art. 29(4) does not restrict the ability of that Signatory to submit a modified list of notifications upon deposit of the instrument of ratification, acceptance or approval', at 73; see $<$ www.oecd.org/tax/treaties/explanatory-statement-multilateralconvention-to-implement-tax-treaty-related-measures-to-prevent-BEPS. pdf>

68. Avi-Yonah and $\mathrm{Xu}$, above n. 61, at 27-28. 
The Civil Society Forum ${ }^{69}$ and the 134 members of the G77 group of developing countries ${ }^{70}$ proposed to give to the UN Tax Committee the status of an intergovernmental body both at the July 2015 Addis Ababa Conference and the July 2016 Nairobi Conference. ${ }^{71}$ The Civil Society Forum advocated for a forum where every country can participate, not just the richest. The Civil Society Forum stated in the declaration that 'a key reason why the global tax system has failed is that more than half of the world's countries are currently excluded from the decision-making process on global tax standards". Therefore, the Civil Society Forum stressed that 'we need to fundamentally change the tax rules, and not having every country represented in writing those rules to make sure they work for everyone is not only undemocratic but also unfair'. ${ }^{72}$ The G77 developing countries called, as a precondition, for more cooperation in international tax matters 'a more inclusive mode of discussion and a seat at the table in the policy decision making on financing for development'. ${ }^{73}$

Despite these arguments, the proposals were rejected. Developed countries decided not to give the upgrade to the UN Committee since in their opinion the OECD has a leading role in all tax issues. Therefore, it is submitted that the work of the UN Committee as a representative of developing countries will be limited due to the predominant role of the OECD. Another reason is also the UN Committee's lack of resources to engage permanent staff to carry out tax research and/or to

69. According to its website, an open forum for people to engage with the challenges of building a world where all can flourish; see <http:// civilsocietyforum.com/> (last visited 22 March 2017).

70. A group of, at the date of establishment (15 June 1964), 77 and presently 134 developing countries providing the means for the developing world to articulate and promote its collective economic interests and enhance its joint negotiating capacity on all major international economic issues in the United Nations system, and promote economic and technical cooperation among developing countries; see <http:// schemaroot.org/region/international/government/united_nations/ group_of_77/> (last visited 22 March 2017).

71. 14th session of the UN Conference on Trade and Development (UNCTAD 14) in Nairobi; see <www.ipsnews.net/2016/08/developingnations-seek-tax-body-to-curb-illicit-financial-flows/> (last visited 22 March 2017)

72. In its declaration form, the Addis Ababa Civil Society Forum on Financing for Development of 12 July 2015, the Civil Society states: 'We reiterate the need and strongly recommend the establishment of an intergovernmental, transparent, accountable, adequately resourced tax body with universal membership that leads global deliberations on international tax cooperation. Such a body will strengthen the ability of developing countries to generate significant sustainable financing for development through, for example, combating corporate tax dodging in developing countries and balancing the allocation of taxing rights between source and residence countries. It should also support the efforts of peoples in developing countries to develop their own progressive, rights-based, equitable tax systems and laws, free of such pressures imposed by lenders and developed country governments', at 4; see <www.icae2.org/images/Addis\%20Ababa\%20CSO\%20FfD \%20Forum\%20Declaration\%20-\%2012\%20July\%202015.pdf> (last visited 22 March 2017).

73. UN News Centre, 14 July 2015: UN Negotiations resume on financing framework to advance global development; see <https://www. theguardian.com/global-development-professionals-network/2015/jul/ 15/addis-ababa-talks-risk-deadlock-over-un-agency-for-tax-ffd3financing-for-development> (last visited 22 March 2017). advise developing countries. ${ }^{74}$ Notwithstanding these problems, in our view the UN should have a more predominant role and international institutions and the OECD, IMF and World Bank should facilitate this role. The initiative of writing Joint Reports is a first step in this direction, that will not only give the $\mathrm{UN}$ a more prominent role, but will also contribute to mutual understanding. Our recommendation is provided in Section 4.

\subsection{Tax Cooperation vs. Tax Competition}

The reason why developing countries are participating in the BEPS project even though its content has been decided by the BEPS 44 group is not clear, but perhaps some indication could be found, for instance, in the need of countries to receive technical assistance and to gain more specialised knowledge on transfer pricing. The motivation for cooperation between states can also be found in the concept of global justice of Nagel, ${ }^{75}$ where the transformed role of the state has been addressed. ${ }^{76}$ Nagel discusses the problem of how global justice can be achieved. He argues that 'global justice requires global sovereignty' and that 'the most likely path toward some version of global justice is through the creation of potentially unjust and illegitimate global structures of power that are tolerable to the interests of the most powerful current nation-states'. These effective but illegitimate institutions, to which the standards of justice apply, will first increase injustice.

For Dagan - referring to Nagel - the questions that should be asked in international tax and the achievement of global justice are: 'if states' coercive power is eroding due to competition and if they now find it difficult to treat their citizens justly, what, if anything, can be done to promote justice? Can we still expect states to uphold principles of justice even if they can no longer do so unilaterally? Can we expect them to cooperate in order to ensure justice? And if they have to rely on the cooperation of other states in order to sustain their sovereign power, does this give rise to a new level of justice duties, across state boundaries??77 In this context, Dagan addresses the shortcoming of the current BEPS Project in the promotion of global justice, which has 'not centered on considerations of justice but, rather, on ways to improve states' ability to collect taxes in light of increasing tax competition', reason why a new way to promote cooperation with justice for all states should be promoted. $^{78}$

For developing countries, the fundamental question is whether in order to raise revenue the solution is interna-

74. This is illustrated by the fact that only one person is permanent staff of the UN Tax Committee, i.e. Michael Lennard. The other participants are members of an Ad Hoc Committee. For an overview of the Committee see <www.un.org/esa/ffd/tax/overview.htm> (last visited 22 March 2017).

75. T. Nagel, 'The Problem of Global Justice', 33 Philosophy \& Public Affairs 2, at 113 and 120 (2005).

76. Ibid., at 146-47.

77. T. Dagan, 'International Tax and Global Justice', SSRN (2016), at 24; see <http://ssrn.com/abstract=2762110> (last visited 22 March 2017).

78. Ibid. 
tional tax cooperation and the implementation of BEPS Actions or rather to have tax competition by introducing incentives to attract investment? To answer this question and to give a voice to developing countries, the World Bank organised in May 2016 the Conference: 'Winning the Tax Wars: Global Solutions for Developing Countries. ${ }^{, 79}$ In respect of corporate taxation, ${ }^{80}$ the discussion in this conference addressed philosophical (and political) questions concerning fair and effective taxation from an international perspective. The World Bank states that: 'the global tax agenda has mainly focused on these issues from the fiscal revenue generation perspective (tax base erosion and tax rate "race to the bottom") and efficiency viewpoint (uncertainty of tax regimes for foreign direct investment and long term profitability of firms). Less attention has been given to how these tax trends are affecting developing countries and who the winners/losers are at the global level. ${ }^{, 81}$

The topics discussed in this conference were, among others, tax competition, tax cooperation and transparency from the perspective of developing countries, also including questions such as (i) how tax competition affects particularly the ability of developing countries to enforce a legitimate contract between government and taxpayer; (ii) how global tax rules could be improved to keep pace with a rapidly changing global business environment; (iii) whether tax competition is needed; and (iv) whether tax cooperation including possible regional and global arrangements is necessary. The debate on these topics has been made available in the World Bank website and it is clear that the World Bank wants to take a leading role in the debate regarding developing countries. ${ }^{82}$ However, it is not yet clear how the findings of this conference will result in concrete proposals for developing countries.

How for instance should the new international regime for exchange of information be accommodated to the needs of developing countries? According to Urinov, a closer study of the global standard, its adoption process and the recent practice indicate that the initiative on automatic exchange of information are intended to establish a platform for regular flow of information mainly between tax havens and some developed countries. It, by and large, ignores the developing countries' participation in the new regime. Urinov warns that in fact, some strict requirements of the standard would

79. Program of the conference; see <www.worldbank.org/en/events/2016/ 04/29/winning-the-tax-wars-global-solutions-for-developingcountries\#2.

80. Other topics also discussed are taxing to promote public goods, tobacco taxes, taxing to promote public goods, carbon taxes.

81. Invitation to the conference available at the website of the World Bank; see <www.worldbank.org/en/events/2016/04/29/winning-the-taxwars-global-solutions-for-developing-countries\#1>.

82. See <http://live.worldbank.org/winning-the-tax-wars> (last visited 22 March 2017) prevent most developing countries from joining the regime anytime soon. ${ }^{83}$

\subsection{Intermediate Conclusion}

In Section 2 we have addressed the shortcoming of BEPS in respect of developing countries. Scholars have addressed mainly the different problems of developing countries, which are not all BEPS-related problems (e.g. tax incentives), the lack of participation and representation of developing countries in the decision-making process of the BEPS Actions, and the limited participation of the UN in the BEPS discussions. International organisations such as the IMF, UN and WB have also addressed the importance to help developing countries to strengthen their tax systems and to achieve Sustainable Development Goals (SDGs), to tackle corruption and to give a voice to developing countries, including small countries, into the debate on international policy. Another problem that has been identified by scholars and international organisations is the allocation of taxing rights between developing and developed countries. The OECD has stated in the 2014 Report that the allocation of taxing rights between countries is outside the scope of BEPS. ${ }^{84}$ However, in our view and as rightly argued in legal scholarship, ${ }^{85}$ this issue should be also in the BEPS Agenda since only a comprehensive discussion will contribute to achieving fairness in the BEPS discussion in respect of developing countries.

We submit that the implementation of BEPS will require more than the options provided in the Multilateral Instrument. Tailored solutions should be introduced for developing countries, taking into account the lack of technical resources (personnel capacity, technical knowledge and economic means) of developing countries. As rightly argued by Bird, the need for tailored solutions in tax policy also 'emphasizes the extent to which sustainable reforms must be developed "in house" by countries themselves'. ${ }^{86}$ Thus, more resources, more time and more tailored solutions are needed for developing countries.

83. V. Urinov, 'Developing Country Perspectives on Automatic Exchange of Tax Information', 1 Law, Social Justice \& Global Development Journal (2015), Warwick School of Law Research Paper; see <http://papers. ssrn.com/sol3/papers.cfm?abstract_id=2684111> (last visited 22 March 2016).

84. OECD (2014), above n. 9, at 1 and 9; see <https://www.oecd.org/g20/ topics/taxation/part-1-of-report-to-g20-dwg-on-the-impact-of-beps-in -low-income-countries.pdf> (last visited 22 March 2017).

85. E.g. M. Lennard, 'Base Erosion and Profit Shifting and Developing Country Tax Administrations', 44 Intertax 10, at 745 (2016); and see S.B. Law, 'Base Erosion Profit Shifting - An Action Plan for Developing Countries EPS', 68 Bulletin for International Taxation 1 (2014); see also Y. Brauner, 'BEPS: An Interim Evaluation', 6 World Tax J, at 10-39 (2014).

86. R. Bird, 'Taxation and Development: What Have We Learned from Fifty Years of Research?', DIIS Working Paper International Development Studies (2013); see <https://www.ids.ac.uk/files/dmfile/Wp427.pdf> (last visited 22 March 2017). 


\section{Arguments Why Developing Countries Might Perceive Fairness in Relation to Corporate Income Taxes Different from Developed Countries}

In a 2003 World Bank publication, Richard M. Bird and Eric M. Zolt mapped arguments why fairness concerns in developing countries may be different from those in developed countries in respect of individual income taxes, wealth taxes and consumption. ${ }^{87}$

There is some evidence that developing countries perceive differently from developed countries the fairness in relation to corporate income taxes as well. In the following we give a few examples of likely differences in perception of fairness between developing and developed countries. These examples will be given in accord-

Their main arguments were:

- developing countries are less capable of using the tax system to redistribute income as income and wealth taxes play a relatively small role in the tax structure of developing countries and individual income taxes are merely a wage withholding tax;

- care must be taken not to complicate individual income taxes;

- it is likely that the consequences of using individual income taxes for influencing economic behaviour are different in developing countries than in developed countries (work vs. leisure, formal vs. grey/ black economy, saving at home vs. portfolio investment outside the country);

- personal income taxes in developing countries should have a 'threshold' well above average income levels;

- the most effective way to reduce inequality in many countries seems likely to be through spending programs targeted at the poor.

Most likely these arguments are still valid. R.M. Bird and E.M. Zolt, 'Introduction to Tax Policy Design and Development', World Bank, at 21-23; see <www.gsdrc.org/document-library/introduction-to-taxpolicy-design-and-development/> (last visited 22 March 2017).

88. Public finance scholars traditionally have defined fairness in terms of horizontal and vertical equity (the quality of being fair and impartial). Horizontal equity is defined by Musgrave and Kaplow as the requirement that equals be treated alike and both define vertical equity as requiring an 'appropriate' pattern of differentiation among unequals. See R.A. Musgrave, The Theory of Public Finance (1959), at 160; L. Kaplow, 'Horizontal Equity: Measures in Search of a Principle', 2 National Tax Journal (Discussion Paper No. 8 5/85, Harvard Law School), at 139 (1989); see <www.law.harvard.edu/programs/olin center/papers/pdf/Kaplow_8.pdf> (last visited 22 March 2017); quoted by J.R. Repetti and P.R. McDaniel, 'Horizontal and Vertical Equity: The Musgrave/Kaplow Exchange', 10 Florida Tax Review 1 (1993), at 607-22; see <http://lawdigitalcommons.bc.edu/cgi/viewcontent.cgi? article $=1706 \&$ context=Isfp $>$ (last visited 22 March 2017) ance with the economic ${ }^{88}$ approach to fairness and the juridical $^{89}$ approach fairness.

\subsection{Differences in Economic Perspective to Fairness}

\subsubsection{Higher Dependency on CIT as Source of Revenue} Developing countries may perceive fair corporate income taxes from an economic perspective as defined by Adam Smith in his Maxim of Equality (subjects of every State should contribute in proportion to the revenue which they enjoy under the protection of the State) differently from developed countries for several reasons. ${ }^{90}$ First, the corporate income tax (CIT) as percentage of GDP in developing countries is much higher than in developed countries, to wit $10 \%$ of GDP, where it has been a constant 3\% of GDP in the period 1980-2016 in developed countries despite a sharp fall in statutory tax rates from on average $50 \%-25 \%$ in this period. Therefore, developing countries may be for instance more sensitive to BEPS and, as the OECD rightly remarks, given 'developing countries' greater reliance on CIT revenues, the impact of BEPS on these countries is particularly damaging'. ${ }^{91}$

89. Tax scholars are using the concept of fairness as justice to restrict the behaviour of the taxpayer by claiming the moral duty of the taxpayer to pay their fair share. Some tax scholars have addressed the concept of fairness in respect of the role of the citizen (taxpayer) in a political community. The approach of tax scholars results in fairness between taxpayers who should abstain from engaging in aggressive tax planning. However, one of the drawbacks is that the concept of fairness is used without having a proper definition of what is fairness and how fairness can be achieved. The consequence is that fairness in taxation is a blurred concept that may also, from a juridical perspective, have different meanings. S.J.C. Hemels, 'Chapter 18: Fairness: A Legal Principle in EU Tax Law?', in C. Brokelind (ed.), Principles of Law: Function, Status and Impact in EU Tax Law (2014); See also S.J.C. Hemels, 'Fairness and Taxation in a Globalized World' (2015); see <http://ssrn.com/abstract= 2570750> (last visited 22 March 2017). See also J.L.M. Gribnau and A.G. Jallai, 'Good Tax Governance and Transparency. A Matter of Ethical Motivation', 6 Tilburg Law School Legal Studies Research Paper Series (2016). See also R. Happé, 'Fiscale ethiek voor multinationals', 144 Weekblad fiscaal recht 7108 (2015), at 944 and 953. See also R. Happé, 'Belastingethiek: een kwestie van fair share', Belastingen en ethiek, 243 Geschriften van de Vereniging voor Belastingwetenschap (2011), at 3-69 and 52-53.

90. In his famous 'Wealth of Nations' Adam Smith formulated the following four Maxims (also referred to as Canons) of Taxation that are necessary for a fair tax system: Maxim of Equality, Maxim of Certainty, Maxim of Convenience and Maxim of Economy. See A. Smith, An Inquiry into the Nature and Causes of the Wealth of Nations (1904); see <www.econlib. org/library/Smith/smWN21.html> (last visited 22 March 2017). See also T. Seth, Canons of Taxation Enunciated by Adam Smith - Discussed! (1948); see <www.economicsdiscussion.net/taxes/canons-oftaxation-enunciated-by-adam-smith-discussed/1948> (last visited 22 March 2017).

91. Press release. First meeting of the new inclusive framework to tackle Base Erosion and Profit Shifting marks a new era in international tax cooperation; see <www.oecd.org/ctp/first-meeting-of-the-new-inclusiveframework-to-tackle-base-erosion-and-profit-shifting-marks-a-new-era -in-international-tax-co-operation.htm>. 'Given developing countries' greater reliance on CIT revenues, the impact of BEPS on these countries is particularly damaging'. 


\subsubsection{Higher Dependency on Tax Incentives as a Method to Attract Investment}

Tax incentives play a more important role in attracting foreign capital than in developed countries. Instead of a race to the bottom in terms of CIT-rates, in developing countries what IMF authors S.M. Ali Abbas and Klemm refer to as partial race to the bottom takes place, where rates have fallen to almost zero due to these tax incentives. ${ }^{92}$ Although States intentionally provide these tax incentives, one may wonder whether Adam Smith's Maxim of Equality is upheld by such tax systems. Moreover, in developing countries the widespread exemptions are often provided in non-transparent ways and with a high degree of discretion..$^{93}$ Nevertheless, developing countries may perceive their system as being fair, at it is perceived as the only way to be competitive.

\subsubsection{Different Viems on Level Playing Field for the Digital and the Traditional Economy}

Developing countries have other views on what is fair than developed countries. An example is the corporate income tax rates applied to the digital economy referred to by World Bank president Jim Yong Kim. ${ }^{94}$ The OECD and EU call for a level playing field for the digital economy and the traditional economy. Developing countries apparently feel it is fair to let the digital sector contribute more than the traditional economy because, perhaps in line with Adam Smith's argument for fairness from an economic perspective, they feel this sector of the economy has a greater ability to pay than the traditional economy, that is, in Adam Smith's perception, 'in proportion to the revenue which they respectively enjoy under the protection of the state'. We could not trace any evidence that this sector indeed has such greater ability to pay, and that this sector is able to receive a larger benefit under the protection of the state than the traditional economy. More research on this issue is needed.

92. S.M. Ali Abbas and A. Klemm, 'Partial Race to the Bottom; Corporate Tax Developments in Emerging and Developing Economies'; see <https://ideas.repec.org/p/imf/imfwpa/12-28.html> (last visited 22 March 2017). The authors assembled a data set on corporate income tax regimes in fifty emerging and developing economies over 1996-2007 and analysed their impact on corporate tax revenues and domestic and foreign investment.

93. A. Jewell, M. Mansour, P. Mitra \& C. Sdralevich, IMF Staff Discussion, 'Fair Taxation in the Middle East and North Africa' (2015); see <https:// www.imf.org/external/pubs/ft/sdn/2015/sdn1516.pdf> (last visited 22 March 2017)

94. In respect of fair taxation, the World Bank furthermore is concerned with the fact that governments in many developing countries have taxed the ICT sector at rates significantly higher than other services. World Bank president Jim Yong Kim remarked at the World Bank-IMF Spring Meeting 2016 that one of the three possible ways for Ministers of Finance to contribute to the 'Global Connect Initiative's target of 1.5 billion people added to the internet by 2020' is 'Fair taxation of the telecom sector'. 'Governments need to ensure more reasonable and predictable tax levels'. Remarks by World Bank President Jim Yong Kim at the Global Connect Initiative, World Bank-IMF Spring Meetings 2016; see <www.worldbank.org/en/news/speech/2016/04/14/remarks-byworld-bank-group-president-jim-yong-kim-at-the-global-connectinitiative>.

\subsubsection{Different Views on Allocation of Taxation Rights} Developing countries also have different views on the allocation of taxation rights on business profits. The UN for example did not amend its Model Tax Treaty in line with the new Article 7 OECD. The underlying reason may be fear of loss of revenue as well as fear of complicating the allocation of profits to PEs, if not only internal dealings are part of a transaction with a third party (sales of goods, delivery of services to third party, but all internal dealings including internal loans and internal disposal of know-how) should be rewarded arm's length.

In respect of transfer pricing, developing countries stress the importance of simplicity (the so-called sixth method, which is used in a number of developing countries). ${ }^{95}$ The problems in the implementation of BEPS Actions related to transfer pricing have been also pointed out by Espinel taking into account the Colombian experience. Even though Colombia as one of the OECD accession countries has adopted the BEPS Action Plan, the implementation of BEPS Transfer Pricing Actions 8-10 does not 'seem practical or achievable in the short term'. Transfer Pricing Legislation was introduced in the 2004 Tax Reform and substantially amended in the 2012 Tax Reform. Therefore, as rightly argued by Espinel, if a 'country has just finished understanding and/or implementing a transfer pricing regime, how can such a country now begin implementing the outcome of the BEPS initiative? What is in it for them?' ${ }^{96}$ The answer is adopting the proposed measures will result in more revenue, but the problem will be that the application of transfer pricing rules will result in more disputes not only affecting the multinationals but also countries. Espinel rightly states that 'disputes are now affecting not only MNEs, but also countries themselves, as tax that is not paid in one jurisdiction is paid in the other. ${ }^{97}$ This concern is more important now since the allocation of taxing rights between residence and source has been left outside the scope of BEPS. Developing countries need to have a competitive treaty network if they are to implement all BEPS proposals and at the same time

95. See, for the Sixth Method, OECD, 'Transfer Pricing Comparability Data and Developing Countries' (2014); and M.G. Malla and A. Carrera, 'Commodities Transfer Pricing: Revisiting the Sixth Method in Latin America', 25 Transfer Pricing Report 422 (2016).

96. M.I. Espinel Coral, 'BEPS Initiative in Colombia: Transfer Pricing for the Modern World', 23 International Transfer Pricing Journal 4, at 318-22 (2016).

97. Ibid., at 322 
want to be able to attract foreign investment. ${ }^{98}$ Furthermore, as rightly stated by Wagenaar, restriction of treaty access for instance by introducing the LOB or PPT clause can give 'rise to both domestic and treaty policy questions for developing countries, which should reconsider the appropriate level of taxation on investors from non-treaty states. In the longer run, these countries should consider obtaining similar benefits for local business by expanding their treaty network'. ${ }^{99}$

\subsubsection{Different Viems about Fair Tax Systems and Fair and Efficient Tax Administrations}

In response to the recognition that BEPS is a global problem, the African Tax Administration Forum (ATAF) organised a Consultative Conference on New Rules of the Global Tax Agenda in Johannesburg, on 18 and 19 March 2014. In its Discussion Paper entitled 'The Global Tax Agenda and Its Implications for Africa', 100 ATAF stated that in developing countries, beyond its fiscal role, the tax system has a more substantive role: it is an important tool for good governance and the basis for the social fiscal contract between governments and its citizens and corporations. Tax revenues are vital to finance their development agenda and the redistribution of incomes, thus contributing the poverty alleviation. In a context where the recent global financial crisis has reduced the importance of official development assistance (ODA) as a reliable source for financing post-2015 Millennium Development Goals (MDGs), developing countries are beginning to realise that the achievement of the MDGs and economic goals (i.e. market reforms, promotion of private sector investment, industrialisation and promotion of regional programmes and development, etc.) will depend heavily on domestic tax revenues. Consequently, creating robust and equitable domestic tax policies and implementing a fair and effective international tax system through international cooperation become primordial.'

ATAF is also concerned about a fair tax design and fair tax administrations, as is reflected in a Joint Statement on Cooperation between the African Development Bank and the African Tax Administration Forum: 'Convinced that taxation is essential to sustainable development, and that all sectors of society should work together to promote fair and efficient tax systems and administrations

98. In general, developing countries are depending on withholding taxes on royalties, interest, and technical services whereas in the international tax policy of developed countries these withholding tax rates are low or zero. In some developed countries (e.g. the Netherlands) withholding taxes on royalties, interest, and technical services even do not exist. If there are developing countries with no tax treaty network, and the BEPS proposals were to be universally adopted, 'companies in such countries would most likely fall back on domestic law of the source countries'. In developing countries, withholding tax can be relatively high and without any treaty applicable, international groups may leave to other countries with treaty network that can provide a reduced withholding tax rate or no withholding tax rate. Therefore, Wagenaar argues that developing countries should have a treaty network. Wagenaar (2015), above n. 40, at Section 3.5.

99. Ibid., at Section 4

100. Discussion Paper available at the website of the African Tax Research Network; see <atrnafrica.org/atrn/documents/download/8> that will ensure that each country receives the fruits of its own economic achievement and, at the same time, improves its overall governance'.

The concerns of ATAF are important since these type of organisations are one of the three pillars ${ }^{101}$ of the OECD in translating the BEPS Action Plan into practical support for lower capacity developing countries. ATAF's concerns in the context of 'The Global Tax Agenda and its implications for Africa' show the BEPS Multilateral instrument and the BEPS Inclusive Framework should ensure that each country including developing country benefits from BEPS by raising more revenue, acquiring more technical expertise or by receiving a part of the revenue that the other country has obtained in part due to the efforts of the country.

\subsection{Differences in Juridical Perspective to Fairness}

\subsubsection{Equality: Groups of Companies}

One of the issues of fairness from a juridical perspective is equality. Developing countries may have different ideas about equality compared to developed countries in respect of the design of CIT law, especially where it concerns groups of companies. Like many other developing countries, Tanzania, for example, abolished the participation exemption in Section 54(2) of the Income Tax Act 2004 as from July 2012, as it was considered not fair that contracts were not respected. Tanzania for the same reason does not have a group treatment regime. ${ }^{102}$

Developing countries generally also have other perceptions on the juridical fairness of withholding taxes, not in the least also for the economic reason that withholding taxes are simple and reliable sources of revenue. Often developing countries have high withholding taxes on all three sources of passive income (dividend, interest and royalties). An exception is Colombia, a country that does not levy dividend withholding tax at the time of writing (November 2016). The Colombian government proposed in its 2012 Tax Reform Bill introduction of a $4 \%$ tax on dividends. There was opposition from different interest business groups and legislators in the Congress to this proposal. The business associations argued that the dividend withholding tax would unfairly 'constitute double taxation, first on corporations and again

101. According to the OECD these three main pillars are: (1) the direct participation of developing countries and of Regional Tax Organisations in the Committee on Fiscal Affairs of the OECD and all technical working groups; (2) the set-up of Regional Networks of tax policy and administration officials on BEPS in five regions to ensure the participation of countries that are not able to regularly attend the Paris-based meetings; (3) capacity building support, including the development of toolkits, to assist countries implement solutions to tackle BEPS; see <www.oecd. org/ctp/beps-frequentlyaskedquestions.htm> (last visited 22 March 2017).

102. See W.A. Mgimwa, 'Speech by the Minister for Finance Introducing to the National Assembly the Estimates of Government Revenue and Expenditure for the Fiscal year 2012/2013', at 60; see <www.mof.go. tz/mofdocs/msemaji/Budget\%20english\%202013.pdf> (last visited 22 March 2017) 
on shareholders' ${ }^{103}$ The tax reform submitted to the Colombian Congress in October $2016^{104}$ contains a proposal for a dividend withholding tax. ${ }^{105}$ Due to the previous antecedents in the Colombian Congress regarding the fairness for companies of this tax, it is not yet clear whether this dividend withholding tax will be approved by the Congress.

\subsubsection{Equal Treatment/Non-Discrimination}

Courts of developed and developing countries may have different views on the interpretation of Article 26 International Covenant on Civil and Political Rights as well as on the non-discrimination provisions in tax treaties. For example, the Dutch Supreme Court in its application of this article tests whether:

- the legislation causes unequal treatment;

- there is no objective and reasonable justification for the unequal treatment.

Moreover, the Dutch Supreme Court applies a quantitative threshold. ${ }^{106}$ Generally, in these non-discrimination cases this Supreme Court not only interprets Article 26 ICCPR, but also Article 14 jo. Article 1 Protocol European Convention on Human Rights. Generally, the Dutch Supreme Court rules that budgetary problems are no justification for the unequal treatment. However, in its decision of 29 January 2016, V-N 2016/7.17, ${ }^{107}$ the Supreme Court ruled that taking into account the acute revenue problems resulting from the economic crisis and the incidental character of the rule in question

(a crisis levy on 'high wage employees') and the specific circumstances of the taxpayer did not fail to strike a fair balance between the interest of the taxpayer in question and the state.

103. G.A. Flores-Macias, 'Chapter 3 The Political Economy of Colombia's 2012 and 2014 Fiscal Reforms', in J.E. Mahon Jr, M. Bergman \& C. Arnson (eds.), Progressive Tax Reform and Equality in Latin America, Wilson Center, at 101-27. Specific reference to the role of business associations is made at 108-110; see <www.arts.cornell.edu/gaf44/pdfs/ FloresMacias\%20_\%20Political\%20Economy\%20of\%20Colombia $\% 202012 \% 20$ and \%202014\%20fiscal\%20reforms\%20(single \%20chapter).pdf>.

104. Reuters, 'Colombia Tax Reform to Go to Congress in October: President'; see <www.reuters.com/article/uscolombia-economy-taxationidUSKCN10N2MG?il=0> (last visited 22 March 2017).

105. A proposal has been presented in the final report issued in February 2016 by the Tax Experts Commission (the Commission) ad honorem appointed by the government to analyse and propose amendments on tax matters. The final report provides recommendations for the implementation of a structural tax reform. One recommendation is to introduce 'income tax on dividends paid to either residents or non-residents subject to a $20 \%$ tax deduction if the dividends are paid out of profits that were taxed at the level of the company; therefore, if the applicable income tax rate for a taxpayer is $35 \%$, the effective income tax rate applicable to dividends would be $15 \%$; if the applicable income tax rate is $20 \%$ or less, the dividend will not be taxed' 'Colombia - Tax Experts Commission's final report' (2016).

106. See, e.g. Supreme Court 15 July 1998, No. 31.922, BNB 1998/293, VN 1998/36.4.

107. See, e.g. Supreme Court 29 January 2016, No. 15/00340, V-N 2016/7.17.
We are not aware of any systematic research on this issue. ${ }^{108}$ Nor are we aware of systematic comparative research on the question whether Supreme Courts of developed and developing countries interpret the rules of tax treaty non-discrimination provisions in the same way.

\subsubsection{Certainty}

Another principle on which developing countries may have other views than developed countries is legal certainty in terms of stability, promulgation, non-retroactivity and clarity of laws. Simple legislation for example is more important, amongst others, due to lack of (sufficiently trained and sufficiently paid) tax administrators and judges and the lack of administrative guidance, rulings, concepts, etc. Examples of rules that are difficult to apply for taxpayers, tax administrators and tax judges in developing countries are the application of transfer pricing provisions, the application of tax provisions such as beneficial ownership to prevent tax treaty abuse, and the exchange of information among tax administrations. The BEPS Project and BEPS Action Plan 'brings more challenges including the development of international standards to address the digital economy, hybrid mismatches, redefinition of the concept of permanent establishment, and introduction of complex tax treaty abuse provision such as limitation on benefits among others'. ${ }^{109}$ World Bank president Jim Yong Kim's call for developing countries to strive for more reasonable and predictable tax levels ${ }^{110}$ also shows developing countries do not yet have the same perception as developed countries on the relevance of providing legal certainty to taxpayers.

\subsection{Intermediate Conclusion}

Section 3 addressed the question of whether the perception of fairness between developing countries and developed countries is the same or different. The description in Section 3.1 has shown that both the economic and juridical perceptions of fairness differ between these countries. Section 3.1 shows that the differences in perception of economic fairness arise due to the fact that developing countries have a higher dependence on CIT as source of revenue and on tax incentives as method to attract investment. In addition, developing countries and developed countries have different views (i) on level

108. The Jurisprudence Database of the United Nations Human Rights Office of the High Commissioner; see <http://juris.ohchr.org/> (last visited 22 March 2017), gives an overview of cases amongst others on Art. 26 ICCPR.

109. See Valderrama (2015), above n. 7, 615, at 623

110. Remarks by World Bank President Jim Yong Kim at the Global Connect Initiative, World Bank-IMF Spring Meetings 2016 in the context of bridging the 'digital divide': more than four billion people without internet access and $90 \%$ of them living in developing countries, 'If we are to bring these sorts of benefits to all countries - and to achieve SDG targets - we have to increase our efforts exponentially. Ministers of Finance can contribute in three ways: First, fair telecom taxation. Governments in many developing countries have taxed the ICT sector at rates significantly higher than other services. Governments need to ensure more reasonable and predictable tax levels'; see <www. worldbank.org/en/news/speech/2016/04/14/remarks-by-world-bankgroup-president-jim-yong-kim-at-the-global-connect-initiative> 
playing for the digital and the traditional economy; (ii) on allocation of taxing rights and (iii) on fair tax systems and fair and efficient tax administrations. These differences are not only due to the BEPS Projects but also due to the economic development of a country.

Section 3.2 shows that there are also differences in the juridical perspective to fairness mainly regarding equality and certainty. Developed and developing countries have different views regarding equal treatment to group of companies. They may also have different views on the interpretation of non-discrimination provisions in International Human Right Conventions and tax treaties; and on the importance of the principle of certainty in drafting tax law and instruments to provide legal certainty to taxpayers such as rulings.

How to overcome these differences? The following section will provide our recommendations to address the differences in perception.

\section{Recommendations}

This section aims to answer the question what, if anything, can be done to achieve fairness for both developed and developing countries? Below we give some by no means exhaustive - recommendations.

\subsection{Tax Principles, Code of Conduct of Taxation} and Broadening of the BEPS-Agenda

In 1998 the OECD formulated the Ottawa principles of taxation, which to a high extent reflect Adam Smith Canons ${ }^{111}$ and thus an economic perspective: neutrality, efficiency, certainty and simplicity, flexibility and effectiveness and fairness. The OECD explains the principle of fairness as: 'The potential for tax avoidance and evasion should be minimalised while keeping counter-acting measures proportionate to the risks involved. ${ }^{112}$ These principles reflect an economic approach to fairness.

For this, Richard Murphy's Code of Conduct of Taxation would be a good starting point as the fairness principles are reflected in this Code. The Code was developed to favour the interpretation of law according to its purpose and the intention for which it was implemented. This Code has fourteen principles of taxation based on the Universal Declaration of Human Rights. These principles include, among others, the duty of the state to protect its citizens, to provide public goods for its citizens, to refrain from discrimination, etc. ${ }^{113}$

111. Smith (1904), above n. 90

112. OECD, 'Implementation of the Ottawa Framework Conditions The 2003 Report' (2003); see <www.oecd.org/tax/administration/ 20499630.pdf> (last visited 22 March 2017); Referred to also in the 5 October 2015 Report OECD, 'BEPS Action 1 Addressing the Challenges of the Digital Economy' (2015); see <www.oecd.org/tax/addressing-the -tax-challenges-of-the-digital-economy-action-1-2015-final-report -9789264241046-en.htm>, Annex A and Annex C.

113. R. Murphy, 'A Code of Conduct for Taxation' (2007); see <www. taxresearch.org.uk/Documents/TaxCodeofConductFinal.pdf> (last visited 22 March 2017).
We recommend the OECD, IMF, UN and WB (four IOs) to develop a set of tax principles jointly. One of the issues that should be addressed in the discussion is the perspective of the different countries on whether the social contract theory underlies taxation and if so how the concept of 'fair share' to be paid by the taxpayers could be made operable in such a way that it offers both taxpayer and the state sufficient certainty on the amount of tax to be paid. Academic research may offer some guidance in this.

We also recommend the four IOs to collectively work on the follow-up of the OECD's Report on the impact of BEPS in Low Income Countries (2014) and the IMF Policy Paper Spillovers in International Corporate Taxation (2014) and to broaden the scope of the BEPS project. Comparative research by academic researchers may elevate the discussion to a higher level.

In light of the BEPS Agenda, further research should also be carried out on the practical implementation of BEPS in developing countries. It is not yet clear what is the motivation for countries outside the BEPS 44 Group to participate as BEPS Associate and to implement BEPS. It is also not clear how countries will implement BEPS including the role of the Legislative, Executive and Judiciary in the implementation of BEPS, and whether the implementation of the BEPS Actions will be compatible with the rules of countries to attract investment. Nor is it clear how this implementation will influence the decision to invest by multinationals operating worldwide.

\subsection{Participation of the UN and Joint Work of the Four IOs}

As rightly stated by Dagan, BEPS has centred on achieving tax revenue rather than on considerations of justice (Section 2.5). The initiative of the World Bank and IMF of July 2015 to deepen the dialogue with developing countries on international tax issues and to develop tools to help member countries to evaluate and strengthen their tax policies, as well as OECD's clear intention to involve developing countries in the implementation of the BEPS project is a good step towards achieving cooperation between states. However, the authors recommend that this initiative should also include the UN that has experience in the design of international tax proposals for developing countries.

At this stage, the role of the $\mathrm{UN}$ is limited mainly due to the rejection by developed countries in the July 2015 Financing for Development Conference of the proposal to give to the UN Tax Committee the status of intergovernmental body. The involvement of the UN is necessary to ensure that the initiative of the IMF and World Bank goes beyond technical assistance, that it gives a voice to developing countries and that it will result in concrete proposals for cooperation between developing and developed countries. Notwithstanding the acknowledgment by developed countries of the leading role played by the OECD and the lack of resources of the $\mathrm{UN}$, we recommend the $\mathrm{UN}$ to have a larger role in the discussion of BEPS with some additional financ- 
ing by the World Bank since this institution has also addressed the importance of giving a voice to developing countries in the setting of international tax standards (Section 2.4.2).

\subsection{Revenue Sharing}

In the words of Rawls, a proper distribution of benefits and burdens of social cooperation includes a fair division of taxation rights between states. ${ }^{114}$ The philosophical approach to fairness aims for citizens to contribute to society and for multinationals to refrain from using aggressive tax planning since it will not be fair vis-à-vis local business and it will reduce compliance from local business. Mechanisms of sharing of extra revenue that will be the result of BEPS measures between developing and developed countries should be included in the agen$\mathrm{da}$ of the four IOs. In order to address this issue, statistical information on the benefits and costs of BEPS should be collected either by the four IOs or by academic researchers. This still open issue will affect how developing countries perceive the legitimacy of the BEPS proposals.

The approach to revenue sharing has been made in the past by one of the authors in respect of exchange of information stating that 'exchange of information may result in more revenue for countries that have the technological and administrative resources to deal with the information exchanged. Developing countries will need an additional motivation to exchange information, and this could be for instance revenue sharing between developed and developing countries.' ${ }^{, 15}$

An empirical study carried out by Paolini et al. states that 'revenue sharing compensates the developing economy for the loss of tax base, the cost of implementing tax auditing and (in case of firm relocation) also for the financial subsidy paid to firms to stay'. ${ }^{116}$ Therefore, this study concludes that it is possible for developing countries to voluntarily sign a tax treaty that includes exchange of information, tax audit and revenue sharing. ${ }^{117}$ Furthermore, in the field of administrative assistance, as rightly argued by Turina, it is relevant to design an incentive-based approach (i.e. revenue sharing) as a policy tool to ensure ex ante compliance with administrative assistance agreements. ${ }^{118}$

114. Rawls, justice provides 'a way of assigning rights and duties in the basic institutions of society and they define the appropriate distribution of the benefits and burdens of social cooperation'. A Theory of Justice, Oxford University Press, Oxford, (1971), at 2; See also J. Rawls, 'Justice as Fairness', 67 The Philosophical Review 2, at 178 (1958); J. Rawls, 'Justice as Fairness: Political Not Metaphysical', 14 Philosophy \& Public Affairs 3, at 223-51 (1985)

115. See Valderrama (2015), above n. 22, 381, at 358.

116. D. Paolini, P. Pistone, G. Pulina \& M. Zagler, 'Tax Treaties with Developing Countries and the Allocation of Taxing Rights', 38 European Journal of Law and Economics 2 (2014).

117. Ibid.

118. A. Turina, 'Information-Based Administrative Tax-Cooperation, Consolidating Standards, Emerging Actors and Evolutionary Perspectives' (Doctoral Thesis defended at Bocconi University Milan 2013).
4.4 Systematic Research on the Ideas of

Fairness, Equality and Certainty

As mentioned in Section 3.2, developing countries may have other ideas of equality and certainty than developing countries. IMF argues rightly that research is needed on the issue whether all BEPS recommendations are equally relevant to developing countries. Such research is indispensable for the political perspective of fairness and creating legitimacy. Researchers, governments and international organisation should pay more attention to what is meant with fairness in general and to differences in perception between countries more specific in their discussions on how to prevent tax avoidance and tax evasion.

For purposes of the design of a global tax system that is fair and provides both equality and certainty, research and also a political discussion are indispensable on the question of what is 'real economic benefit' (Fair Tax Mark ${ }^{119}$ ) or 'the jurisdiction where the true economic activity occurs' (Tax Justice ${ }^{120}$ ) or 'the economic activity undertaken in that country' $\left(\mathrm{UN}^{121}\right)$ or 'the jurisdiction where profits are generated' $\left(\mathrm{EU}^{122}\right)$ or 'where value is created' (OECD BEPS Action 10 ${ }^{123}$ ).

\subsection{Participation on Equal Footing of Developing Countries}

These authors furthermore recommend that by using the fairness approach, developed countries should ensure that the needs of developing countries are also

119. Recently the founder of the non-governmental organisation 'Tax Justice Network' Richard Murphy took the initiative for a FairTaxMark for UK companies. According to the FairTaxMark website, 'fair tax' means that a business seeks to pay the right amount of tax (but no more) in the right place at the right time; see $<w w w$.fairtaxmark.net/ $>$ (last visited 22 March 2017).

120. Tax Justice Network stated in 2014: 'in a highly globalised world dominated by large multinational corporations, it is essential to ensure that taxes are paid where the true economic activity occurs. Under current global rules, this is often not the case, and companies are able to shift profits around the globe to places where they will be taxed less. This has a particularly devastating impact on developing countries'. See 17 October 2014; <www.taxjustice.net/2014/10/17/fair-taxes-key-fairshare/> (last visited 22 March 2017).

121. The UN, when explaining BEOS Action 13, stated that the information provided in the transfer pricing documentation (profits earned and tax paid, assets owned and number of employees) may be useful for 'tax authorities trying to identify whether an MNE is leaving an amount of income in a jurisdiction that fairly reflects the economic activity undertaken in that country', at 16; see <www.un.org/esa/ffd/tax/BEPS_note. pdf> (last visited 22 March 2017).

122. For the EU Commission, companies should pay taxes where profits are generated and this principle has been undermined by aggressive tax planning. For the Commission, 'The majority of businesses do not engage in aggressive tax planning and suffer a competitive disadvantage to those that do. The aggressive behaviour of these companies distorts price signals and allows them to enjoy lower capital costs, disrupting the level playing field in the Single Market. Small and medium sized businesses are particularly affected by this phenomenon'. Communication from the Commission to the European Parliament and the Council. 'Anti-Tax Avoidance Package: Next Steps towards Delivering Effective Taxation and Greater Transparency in the EU', $\operatorname{COM}(2016) 23$ final, at 2 (28 January 2016); see <http://eur-lex.europa.eu/legal-content/EN/ TXT/PDF/?uri=CELEX:52016DC0023\&from=EN> (last visited 22 March 2017).

123. OECD, 'Aligning Transfer Pricing Outcomes with Value Creation, Actions 8-10 - 2015 Final Reports' (2015); see <http://dx.doi.org/10. 1787/9789264241244-en> (last visited 22 March 2017). 
taken into account. IOs including the UN should develop mechanisms to make sure that participation in the inclusive framework of BEPS Associates is truly on equal footing and that the outcome of the negotiations of the BEPS multilateral instrument is transparent by providing information on what was adopted, and whether the needs/voice of developing countries were also taken into account in the final outcome, that is the BEPS multilateral instrument. Therefore, the authors feel that the outcome of these meetings - including the agenda, and the proposals of developed countries, developing countries and IOs - should be made available on the website of the OECD. In order for this framework to be truly inclusive, the agenda should also be inclusive. Therefore, the discussion should be not only on BEPS issues, but also on non-BEPS issues that have been identified as relevant for developing countries. These issues have been identified in Section 2.1 and are, among others, tax incentives, tax treaty cost/benefit analysis, introduction of transfer pricing rules, and the limited administrative capacity of the tax administration.

Furthermore, the inclusiveness should also result in more participation of the taxpayer including business association, tax advisers' associations, and taxpayers' associations. ${ }^{124}$ Till now the participation has been limited to voluntary participation by these associations in consultations and in some cases position papers regarding the BEPS Actions. ${ }^{125}$ Finally, we believe that BRICS can function as a bridge to reduce the different perspectives of developed and developing countries on tax fairness. ${ }^{126}$

\section{Final Remarks}

Ostwal raised the question 'who will adopt the OECD's plan against BEPS, after all?'127 In order to get these plans adopted, it is essential that global fairness will be achieved for both developing and developed countries. International organisations play an essential role in achieving fairness, even if they do not have the same powers as legislators. We recall Nagel's quotes on this presented in Section 2.5: 'global justice requires global sovereignty' and 'the most likely path toward some version of global justice is through the creation of potentially unjust and illegitimate global structures of power that are tolerable to the interests of the most powerful current nation-states'.

124. An interesting example of this broader participation is the November 2016 Regional Meeting of the Inclusive Framework of BEPS for African French-speaking countries. The event was hosted by the Ministry of Economy and Finance of Tunisia, and organised by the OECD in partnership with CREDAF (Centre de rencontres et d'études des dirigeants des administrations fiscales). The World Bank Group was also represented. Participants included senior officials from Ministries of Finance and Tax Administrations from Algeria, Benin, Burkina Faso, Cote d'Ivoire, Democratic Republic of the Congo, France, Gabon, Guinea, Madagascar, Mauritania, Morocco, Senegal and Tunisia, as well as business representatives (PricewaterhouseCoopers, Cabinet Bile-Aka, Brizoua-Bi et Associés) and members from civil society such as the BEPS Monitoring Group and TUAC; see <www.oecd.org/fr/fiscalite/beps/resume-copresidents-reunion-regionale-du-cadre-inclusif-beps-tunis-2016.pdf>.

125. One of the most active participants regarding BEPS has been the Business and Industry Advisory Committee; see <http://biac.org/focusareas/international-taxation/> (last visited 22 March 2017).

126. The impact of the BRICS on the international tax regime has been thoroughly analysed in Y. Brauner and P. Pistone (eds.), 'BRICS and the Emergence of International Tax Coordination', IBFD (2015).

127. Ostwal, above n. 35. 